\title{
Estimation of soil erosion risk within the Ben Ahmed watershed, using Universal Soil Loss Equation (USLE) and geo-information technology
}

\author{
Nazha Asserar ${ }^{1}$, Hamza Iaaich ${ }^{2}$, Rachid Moussadek ${ }^{3}$, abdelmjid zouahri ${ }^{3}$, and Allal \\ Douira $^{1}$ \\ ${ }^{1}$ Ibn Tofail University Kenitra Faculty of Sciences \\ ${ }^{2}$ Moroccan National Institute of Agricultural Research \\ ${ }^{3}$ Moroccan National Institute of Agricultural research
}

May 18, 2020

\begin{abstract}
The Central areas of Morocco are susceptible to soil erosion due to their complex terrain form and heavy rainfall events. The objective of this study is to quantify soil erosion in the Ben Ahmed watershed, Settat Province, a representative watershed of Central Morocco, using the Universal Soil Loss Equation (USLE) and Geographic Information System (GIS). The soil erosion parameters were mapped using different data sources then overlaid using raster calculation. The $\mathrm{R}$ factor map was developed from the rainfall data with a return period of 20 years, the $\mathrm{K}$ factor map was obtained from the soil map, the factor $\mathrm{C}$ map was generated based on a very high spatial resolution satellite image provided by ESRI servers, a digital terrain model (ASTER) with a spatial resolution of $30 \mathrm{~m}$ was used to develop the LS factor map. P factor map was assumed as 1 for the watershed because conservation practices are absent. The results showed an average annual soil loss of $1.1 \mathrm{t}$ ha- 1 yr- 1 with a standard deviation of 3.7. The spatial distribution of the erosion risk classes indicates $74.5 \%$ of low rates, largely located on agricultural land, while higher rates are local and range from 5 to 88 t.ha-1.year-1. Analysis of the erosion risk map, in comparison with different thematic maps of the various factors of the equation, shows a clear and significant influence of the vegetation cover on the erosion behavior of soils, followed by the topographic factor, particularly the slope steepness.
\end{abstract}

\section{Introduction}

Soil erosion is highly significant as a spatiotemporal phenomenon in many countries (Fistikoglu and Harmancioglu, 2002; Hoyos, 2005; Pandey et al.,2009). Soil erosion is a natural process, where the extent and magnitude of soil loss are controlled by various environmental determinants, such as topography, climate, soil and vegetation (Wischmeier and Smith, 1978; Renard et al., 1997; Mutua et al., 2006; Butt et al., 2010). There are several factors that increase water erosion which are: rainfall, soil type, slope, vegetation type and presence or absence of conservation measures (Khalid chadli, 2016).

In Morocco, soil erosion has been increasing annually. Indeed, in recent decades, the agricultural areas has undergone considerable changes, with specific degradation and soil loss rates, varying from region to another and mainly ranging from 5 to $20 \mathrm{t} / \mathrm{ha} /$ year (Ghanam, 2003).

To date, most studies on soil erosion at large scale have used numerous soil erosion and sediment transport models. In fact, modeling provides quantitative estimation of soil loss in a reasonable time-frame under a wide range of conditions, compared to the field-based methods. In Morocco, research works dealing with soil erodibility and erosion risk were undertaken at different scales. El Garouani et al. (2005) used the USLE in the Oued Jemaa basin (Pre-Rif zone in the North of Morocco). For large scale mapping, El bouqdaoui et al. 
(2005) used the expert-based model LEAM (Land Erodibility Assessment Model), based on the USLE and satellite imagery to evaluate soil loss rates in the Oued Srou Basin.

Universal Soil Loss Equation (USLE) (Wischmeier \& Smith, 1978) and Revised Universal Soil Loss Equation (RUSLE) (Renard et al., 1997) are the most widely used models because of their simplicity, robustness and transparent model structure, minimal data requirement, easy input data availability as well as the compatibility with geospatial platforms (Millward \& Mersey, 1999; Merritt et al., 2003). Despite the inherent limitations of USLE and RUSLE, the versatility of these models integrated with GIS was demonstrated in a wide range of environmental settings and at various spatial scales (Prasanna-kumar, Vijith et al., 2011; Prasannakumar, Shiny et al., 2011; Ranzi, Le, \& Rulli, 2012; Mhangara, Kakembo, \& Lim, 2012; Panagos et al., 2015; Pradeep et al., 2015; Magesh \& Chandrasekar, 2016; Abdo \& Salloum, 2017; da Cunha, Bacani, \& Panachuki, 2017 ; Haregeweyn et al., 2017).

The objective of the present study is to assess the amount of soil loss at Ben Ahmed watershed based on USLE method and GIS (Geographical Information System) techniques, and to prepare potential soil erosion maps of the Ben Ahmed watershed.

\section{Materials and Methods}

\section{Study area}

The Ben Ahmed watershed is located in the region of Casa-Settat (Settat province), $70 \mathrm{~km}$ Southeast of Casablanca in Northwest Morocco, covering 545 ha. The study area receives an average annual rainfall of $400 \mathrm{~mm}$ and is under a semi-arid climatic with a mean minimum and maximum temperature of $9^{\circ} \mathrm{C}$ and $26^{\circ} \mathrm{C}$. Almost $75 \%$ of the area is occupied by agriculture land.

\section{The universal soil loss equation}

The USLE, proposed by Wischmeier and Smith (1978), is applied in several studies worldwide. The input required data reflect the five factors; rainfall erosivity, soil erodibility, topography, crop management and conservation practice. It is described as follow:

$\mathrm{A}=\mathrm{R}^{*} \mathrm{~K} * \mathrm{LS}^{*} \mathrm{C} * \mathrm{P}(1)$

Where:

A: is the average annual soil loss (tons ha $^{-1}$ year $\left.^{-1}\right)$,

$\mathrm{R}$ : is the rainfall erosivity (MJmm ha $\mathrm{h}^{-1} \mathrm{~h}$ year),

$\mathrm{K}$ : is the soil erodibility factor (tons $\mathrm{ha}^{-1} \mathrm{R}$ unit-1),

LS: is the topographic factor (adimensional),

$\mathrm{C}$ : is the cropping management factors (adimensional), and

$\mathrm{P}:$ is the practice support factor (adimensional)

\section{Topographic Factor (LS)}

The (LS) factor reflects the combined effect of slope length and slope steepness on erosion. The empirical equation developed by Wischmeier \& Smith (1978) as follow.

$\mathrm{LS}=(\mathrm{L} / 22.15) \times\left(65.41 \sin ^{2} \mathrm{~S}+4.56 \sin \mathrm{S}+0.065\right)(2)$

For practical reasons of calculation under GIS, we have adopted the following formula: LS = Pow ([flowacc]

* resolution / 221.04) * Pow (Sin [slope] * 0.01745 / 0.09,1.4) * 1.4 where "flowacc" is the flow accumulation,

"resolution" is the spatial resolution of the numerical model of terrain used and "slope" is the slope gradient in degree $\left(^{\circ}\right)$. 


\section{Cropping management factor (C)}

The $\mathrm{C}$ factor is a most important factor that controls soil erosion risk (Knijff et al., 2000) and it reflects the effect of cropping and management practices on the soil erosion rate (Jong, 1994; Biesemans et al., 2000; Patil \& Sharma, 2013). For our case, the land use classes were digitized by photo-interpretation based on the very high spatial resolution satellite image with provided by ESRI (C) servers.

\section{Rainfall-runof f erosivity $(R)$ factor}

Rainfall-runoff erosivity is defined as the intrinsic capacity of the rain to cause soil erosion, and amount, intensity, terminal velocity, drop size and drop size distribution of rain are the variables affecting total erosivity of a rain event ( Blanco-Canqui and Lal , 2008). According to Wischmeier and Smith (1978) and Renard et al. (1997), estimation of $\mathrm{R}$ factor requires total rainfall energy (E) and maximum 30 min rainfall intensity (I30) of storm events for at least 20 years. With the lack of sufficient return period climate data in the study area, the $\mathrm{R}$ factor was calculated adopting the modified formula of Rango and Arnoldus (1987). Which is defined as Eq (3).

$\log R=1.74 . \log \sum_{i=1}^{12}(P i 2 / P)+1.29(3)$

\section{Support practice $(\mathrm{P})$ factor}

The $\mathrm{P}$ factor indicates the significance of support practices, which reduce soil loss by modifying the flow pattern, grade or direction of surface runoff and by reducing the rate of runoff (Wischmeier and Smith, 1978; Renard and Foster, 1983). It varies from 0 to 1, according to the practice adopted and slope. In our case, the value assigned to the factor $\mathrm{P}$ is 1 for the whole watershed, since the anti-erosion measures are absent.

\section{Soil Erodibility Factor (K)}

The soil erodibility factor K represents the susceptibility of soil particles to be detached (Renard and al., 1997). K is strongly related to the physical properties of the soil and plays an important role in soil conservation strategies (Shabani, Kumar, \& Esmaeili, 2014). All of the K factor equations are related to the soil texture, soil organic matter, and percentage of sand, silt, and clay in the soil (Millward \& Mersey, 1999). It is expressed in t.haMJ ${ }^{-1} \cdot \mathrm{mm}^{-1}$, and determined according to the following formula (Eq. 4).

$\mathrm{K}=2.77 \mathrm{M} 1,14.10-7(12-\mathrm{OM})+4.28(10-3)(\mathrm{SS}-2)+3.29(10-3)(\mathrm{PP}-3)(4)$

Where OM is the soil organic matter content, $\mathrm{M}$ is the indicator of the soil textural class ((\% fine sand+silt) $\mathrm{x}(100-\%$ clay $)$ ), SS and PP represent the soil structure and permeability classes.

\section{Results}

\section{Topographic factor (LS)}

Topographic factor represents the influence of slope length and slope steepness on erosion process. LS is calculated using the formula mentioned in the methodology section, using an ASTER type digital terrain model with a spatial resolution of $30 \mathrm{~m}$. LS values obtained in the Ben Ahmed watershed range from 0 to 4.25 (Figure 1).

Figure 1 here

\section{Cropping management factor (C)}

Currently, due to the variety of land cover patterns with spatial and temporal variations, satellite remote sensing data sets are used for the assessment of $\mathrm{C}$-factor (Karydas et al., 2009). Based on our land cover mapping, the results showed that the $\mathrm{C}$ factor ranged from 0 to 1 . The land use-land cover of the Ben 
Ahmed watershed was classified with three land cover classes, namely, agriculture land which represent $74,5 \%(\mathrm{C}=0,1)$, bare land representing $22,4 \%(\mathrm{C}=1)$ and built-up $(\mathrm{C}=0)$ representing $3,1 \%$. These land use-land cover features are represented in Table 1 and Figure 2.

Table 1 here

Figure 2 here

\section{Rainfall-runoff erosivity (R) factor}

Several studies (Jain et al., 2001; Dabral et al., 2008) revealed that the soil erosion rate at the watershed level is more sensitive to rainfall. In Ben Ahmed watershed, the mean annual rainfall is $548.83 \mathrm{~mm}$. It is calculated by reporting the average annual precipitation values measured between 1969 and 2002 in the surrounding catchment area. The R-value of Ben Ahmed watershed obtained from annual and monthly precipitation averages is 75.67 ( $\mathrm{MJ} * \mathrm{~mm} /$ ha $*$ hour) (Table 2).

Table 2 here

\section{Support practice $(\mathrm{P})$ factor}

The most conservative practices of soils are contour crops, alternating strips or terraces, reforestation in banquettes. According to the Wischmeier equation, $\mathrm{P}$ is equal to 1 if none of these practices exist in watersheds, which is the case of our study area.

\section{Soil Erodibility Factor (K)}

The evaluation of the K-index in the Ben Ahmed watershed was based on the 1 / 100.000 soil map, supplemented by data analysis of studied soil (texture, structure, organic matter, permeability). There are 5 soil types within the Ben Ahmed watershed, $\mathrm{K}$ values related to the different soil types have been estimated from the USLE Nomograph (Wischmeier and Smith, 1978). By plotting the K values in respect to different soil types, the soil erodibility map of the study area was elaborted (Figure 3 ). The $\mathrm{K}$ factor map shows a maximum value of 0.43 and minimum value of 0.007 , with $25.5 \%$ of the soil showing very low erodibility ( $\mathrm{K}$ $<0.05$ ), represented by the vertisols and isohumic soils. The moderate values of erodibility ranging between 0.1 and 0.2 , were reported in the calcareous regosols, covering $3.8 \%$ (20 ha) of the total catchment area, while for clayey regosols, the $\mathrm{K}$ value is high, ranging from 0.2 to 0.4 . The maximum $\mathrm{K}$ value (0.43) was reached for rendzinas. Spatial distribution of $\mathrm{K}$ value is shown in Table 4. From this study, it has been found that very low $\mathrm{K}$ factor $(<0.05)$ was found in $25.5 \%$ of the total area while major portion $(59.2 \%)$ of the total basin has recorded very high $\mathrm{K}$ values $(\mathrm{K}>0.4)$.

Table 3 here

Figure 3 here

\section{Evaluation of soil losses}

After completing data input procedure and preparation of the appropriate maps as GIS raster layers, they were overlaid using the "Raster calculator" module of the GIS software "ESRI ArcGIS (c)" in order to estimate of the potential rate of soil erosion. In order to predict the annual average soil loss rate in the Ben Ahmed basin, all parameters of the USLE model are overlaid using multiplicative function of the Raster calculator. The soil erosion map (Figure 4) represents the spatial distribution of potential annual average soil loss rates of the study area showing a maximum value of $0.88 \mathrm{t} / \mathrm{ha} / \mathrm{yr}$ and minimum of $0 \mathrm{t} / \mathrm{ha} / \mathrm{yr}$ distributed in the total study area.

Our study revealed that $90.1 \%$ of the total study area is characterized by an erosion rate ranging between 0 and $2.5 \mathrm{t} / \mathrm{ha} / \mathrm{yr}$, while the moderate values of rate soil loss are ranging between 2.5 and $10 \mathrm{t} / \mathrm{ha} / \mathrm{yr}$ cover 
$8.2 \%$ of the total catchment and the area with soil loss rate greater than $10 \mathrm{t} / \mathrm{ha} / \mathrm{yr}$ cover $1.7 \%$ of the total area (Table 4).

Table 4 here

Figure 4 here

\section{Discussion}

The GIS analysis was carried out for USLE to estimate annual soil loss on a pixel-by-pixel basis and the spatial distribution of the soil erosion in the study area. This treatment makes it possible to subdivide the study area (545 ha) into 4 distinct units.

Due to insufficient information on climatic data (R-factor), and the absence of anti-erosion practices (Pfactor) in the study area, only the values of erosive potential were drawn. The other factors (K, LS, C) of the equation are described as a digital map, and the three digital layers of the equation are overlaid to obtain the spatial distribution of the erosive potential in the basin (Figure 4).

The assessed average annual soil loss rate of Ben Ahmed watershed was grouped into different classes based on the minimum and maximum values and the spatial distribution of each class is presented in Figure 4 . The grouping of different soil erosion severity zones was carried out by considering the field conditions. The results presented in table 4 show that about $94.2 \%$ (504 ha) of the study area is classified as low potential erosion risk (0-5t/ha/yr), while the rest of the area is under moderate to high erosion risk. In terms of actual soil erosion risk, the study area has $4.1 \%$ moderate (5-10 t/ha/yr), and 1.7\% high ( $>10 \mathrm{t} / \mathrm{ha} / \mathrm{yr})$ erosion risk levels. The spatial pattern of classified soil erosion risk zones indicates that the areas with low erosion risk are located in the agriculture land and represent $74.5 \%$ presented by the class $\mathrm{C}$ of 0.1 , while the area with high erosion risk is in bare land and built-up, presented by the class $\mathrm{C}$ of 1 . The spatial pattern of annual averages soil erosion risk map shows high spatial correlation with $\mathrm{C}$ factor, and it indicates the role played by cover in controlling soil losses in study area. The lands in our area are almost flat, with low LS values ranging from 0 to 4.5 .

The high value of $\mathrm{K}$ factor are found in rendzinas $(>0.4)$, and the moderate value ranging between 0.10 and 0.44 are found in calcareous and clayey regosol, while the vertisols and isohumic soil show low values of $\mathrm{K}$ factor $(<0.05)$, similar to results found by Lahlaoi et al. (2015) at the Oued El Maleh watershed.

The average soil erosion rate recorded in our study area ranges from 0 to $88 \mathrm{t} / \mathrm{ha} / \mathrm{yr}$ with a mean of 1.1 $\mathrm{t} / \mathrm{ha} / \mathrm{yr}$ and a standard deviation of $3.7 \mathrm{t} / \mathrm{ha} / \mathrm{yr}$, which remains spatially variant and lower than the rate found by Ouallali et al. (2016), in the Wadi Arbaa Ayacha watershed (Western Rif, Morocco) with a mean of 8t/ha/yr. At the Nakhla watershed level, 65 t/ha/year was estimated by Tribak et al. (2012), 37 t/ha/year at the Khemis basin (Khali Issa et al., 2014) and 224 t/ha/year at the Oum Er-Rbia watershed (Yjjou et al., 2014).

\section{Conclusion}

A quantitative assessment of average annual soil loss in Ben Ahmed watershed was made with GIS based USLE equation considering rainfall, soil, land use and topographic datasets. The average erosion rate in Ben Ahmed watershed ranges from 0 to $88 \mathrm{t} / \mathrm{ha} /$ year with an average of 1.1t/ha/yr and a standard deviation of $3.7 \mathrm{t} / \mathrm{ha} / \mathrm{yr}$. The rate of soil erosion varies highly within the landscape mainly due to the changing of land use pattern, topographic abrupt change and soil type distrubution. The results indicate that $94 \%$ of the total area watershed lands are subject to low losses, while $5 \%$ is severely eroded with rate erosion soil ranging from 10 to $88 \mathrm{t} / \mathrm{ha} /$ year. Moreover, rate of soil loss from different sub watersheds is mainly dependent on $\mathrm{C}$, LS and $\mathrm{K}$ factors.

\section{Conflict of Interest Statement}


The authors declare that they have no known competing financial or personal concern that would reflect a conflict of interest of any source regarding the work reported in this paper.

\section{References}

Abdo, H., \& Salloum, J. (2017). Mapping the soil loss in Marqya basin: Syria using RUSLE model in GIS and RS techniques. Environmental Earth Sciences, 76(3), 114. htt p ://dx.doi.org/10.10 07/s12665-017-6 424-0.

Biesemans, J., Van Meirvenne, M., \& Gabriels, D. (2000). Extending the RUSLE with the Monte Carlo error propagation technique to predict long-term average off-site sediment accumulation. Journal of Soil and Water Conservation , 55(1), 35- 42 .

Blanco-Canqui, H., Lal, R. (2008). Principles of Soil Conservation and Management. Springe, Netherlands.

Butt, M.J., Waqas, A ., M, ahmood, CSHRG, R. (2010). The combined effect of vegetation and soil erosion in the water resource management. Water Resources Management 24 (13), 3701e3714 http://dx.doi.org/10.10 07/s11269-010-9627-7.

Dabral, P.P., Baithuri, N., Pandey, A . (2008). Soil erosion assessment in a hilly catchment of North Eastern India using USLE, GIS and remote sensing. Water Resources Management 22 (12), 1783-1798.

Da Cunha, E. R., Bacani, V. M., \& Panachuki, E. (2017). Modeling soil erosion using RUSLE and GIS in a watershed occupied by rural settlement in the Brazilian Cerrado. Natural Hazards, 85(2), $851-868$. htt p ://dx.doi.org/10.10 07/s11069-016-2607-3.

El Garouani,A.,Merzouk,A.,Jabrane,R.,\& et Boussema,M.R.(2005).Analyse spatiale de l'erosion en nappe et de l'infiltrabilite des sols dans le Pre-Rif marocain. Revue Teledetection, 5, 69-80.

Elbouqdaoui, K., Ezzine, H., Badraoui, M., Rouchdi, M., Zahraoui, M. A., \& et Ozer, A. (2005).Approche methodologique par teledetection et SIG de l'evaluation du risque potentiel d'erosion hydrique dans le bassin versant de l'Oued Srou (MoyenAtlas,Maroc). International Journal of Tropical Geology,Geography and Ecology, 29, 25-36.

Fistikoglu, O., Harmancioglu, N.B., (2002). Integration of GIS with USLE in assessment of soil erosion. Water Resources Management 16, 447-467.

Ghanam, M. (2003) La desertifcation au Maroc- Quelle strategie de lutte ? Second FIG Regional Conference Marrakech. Morocco, p 2-5.

Haregeweyn, N., Tsunekawa, A ., Poesen, J., Tsubo, M., M eshesha, D. T., Fenta, A . A ., Adgo, E. (2017). Comprehensive assessment of soil erosion risk for better land use planning in river basins: Case study of the Upper Blue Nile River. Science of the Total Environment, 57 , 45 -108. ht tp://dx.d oi.org/10.1016/j. scitotenv.2016.09.019.

Hoyos, N., (2005). Spatial modeling of soil erosion potential in a tropical watershed of the Colombian Andes. CATENA 63 (1), 85-108.

Jain, S.K., Kumar, S., Varghese, J. (2001). Estimation of soil erosion for a Himalayan watershed using GIS technique. Water Resources Management 15 (1), 41-54.

Jong, S. M. D. (1994). Derivation of vegetative variables from a landsat tm image formodelling soil erosion.Journal of Earth Surface Processes and Landforms , 19(2),16 5-178.

Karydas, C.G., Sekuloska, T., Silleos, G.N. (2009). Quantification and site-specification of the support practice factor when mapping soil erosion risk associated with olive plantations in the Mediterranean island of Crete. Environmental Monitoring and Assessment 149,19-28.

Khalid chadli. (2016). Estimation of soil loss using RUSLE model for Sebou watershed (Morocco). Model. Earth Syst. Environ. (2016) 2:51. 
Khali Issa L., Raissouni A., El Arrim A., Moussadek R., (2014): Mapping and Assessment of Water Erosion in the Khmiss Watershed (North Western Rif, Morocco), CAES, 24, 119-130.

Knijff, J. M., Jones, R. J. A ., \& Montanarella, L. (2000).Soil erosion risk assessment in Europe. Joint Research Centre, European Commission, EUR 19044 EN.

Lahlaoi H., Rhinane H., Hilali A., Lahssini S., Khalile L., (2015): Potential Erosion Risk Calculation Using Remote Sensing and GIS in Oued El Maleh Watershed, Morocco. Journal of Geographic Information System , 7, $128-139$.

Magesh, N. S., \& Chandrasekar, N. (2016). Assessment of soil erosion and sediment yield in the Tamiraparani sub-basin, South India, using an automated RUSLE-SY model.Environmental Earth Sciences, 75(16), 1208. ht tp:// dx.doi.org/10.10 07/s12665- 016-6010-x.

Merritt, W. S., Letcher, R. A ., \& Jakeman, A . J. (2003). A review of erosion and se-diment transport models. Environmental Modelling \& Sof tware, 18(8 - 9), $761-799$. htt p: //dx.doi.org/10.1016/S136 4-8152(03)0 0 078-1.

Millward, A . A ., \& Mersey, J. E. (1999). Adapting the RUSLE to model soil erosion potential in a mountainous tropical watershed. Journal of Catena , 38(2), $109-129$.

Mhangara, P., Kakembo, V., \& Lim, K. J. (2012). Soil erosion risk assessment of the Keiskamma catchment, South Africa using GIS and remote sensing. Environ-mental Earth Sciences, 65(7), 2087- 2102. htt p: //dx.doi.org/10.10 07/s12665- 011-1190-x.

Mutua, B.M., Klik, A ., Loiskandl, W., (2006). Modelling soil erosion and sediment yield at a catchment scale: the case of Masinga catchment, Kenya. Land Degradation \& Development 17 (5), 557e 570. http://dx.doi.org/10.10 02/ldr.753.

Ouallali A., Moukhchane M., Aassoumi H., Berrad F., \& Dakir B., (2016). Evaluation et cartographie des taux d'erosion hydrique dans le bassin versant de l'Oued Arbaa Ayacha (Rif occidental, Nord Maroc). Bulletin de l'Institut Scientifique, Rabat, Section Sciences de la Terre, ndeg 38, 65-79.

Pandey, A., Mathur, A., Mishra, S.K., Mal, B.C., (2009). Soil erosion modeling of a Himalayan watershed using RS and GIS. Environmental Earth Sciences 59 (2), 399-410.

Panagos, P., Borrelli, P., Poesen, J., Ballabio, C., Lugato, E., Meusburger, K., \& Alewell, C. (2015). The new assessment of soil loss by water erosion in Europe. En-vironmental Science \& Policy , 54, 438 -447. htt p: //dx.doi.org/10.1016/j.envsci.2015.08.012.

Patil R. J., Sharma S. K. (2013). Remote Sensing and GIS based modeling of crop/cover management factor (C) of USLE in Shakker river watershed. Proceedings of International Conference on Chemical, Agricultural and Medical Sciences (CAMS-2013). Kuala Lumpur, Malaysia, 29-30 December 2013.

Pradeep, G. S., Krishnan, M. V. N., \& Vijith, H. (2015). Identifi cation of critical soil erosion prone areas and annual average soil loss in an upland agricultural watershed of Western Ghats, using analytical hierarchy process (AHP) and RUSLE techniques. Arabian Journal of Geosciences , 8 (6), 3697-37 11 . htt p: //dx.doi.org/10.10 07/s12517-014-1460-5.

Prasannakumar, V., Vijith, H., Geetha, N., \& Shiny, R. (2011). Regional scale erosion assessment of a sub-tropical highland segment in the Western Ghats of Kerala, South India. Water Resources Management, 25(14), 3715 - 3727 . htt p ://dx.doi.org/10.10 07/s11269-011-9878-y .

Prasannakumar, V., Shiny, R., Geetha, N., \& Vijith, H. (2011). Spatial prediction of soil erosion risk by remote sensing, GIS and RUSLE approach: A case study of Sir-uvani river watershed in Attapady valley, Kerala, India. Environmental Earth Sciences , 64(4), 965 - 972 . htt p ://dx.doi.org/10.10 07/s12665-0110913-3.

Rango A. et Arnoldus H.M.J. (1987). Amenagement des bassins versants. Cahiers techniques de la FAO, 1987. 
Ranzi, R., Le, T. H., \& Rulli, M. C. (2012). A RUSLE approach to model suspended sediment load in the Lo river (Vietnam): Effects of reservoirs and land use changes. Journal of Hydrology, $422-423,17-29$. htt p: //dx.doi.org/10.1016/j. jhydrol.2011.12.0 09.

Renard, K.G., Foster, G.R., Weesies, G.A., McCool, D.K. and Yoder, D.C. (1997) Predicting Soil Erosion by Water: A Guide to Conservation Planning with the Revised Universal Soil Loss Equation (RUSLE). US Department of Agriculture Handbook, No. 703, Washington DC, 1-251.

Renard, K.G., Foster, G.R., (1983). Soil conservation: principles of erosion by water. In: Dregne, H.E., Willis, W.O. (Eds.), Dryland Agriculture. Agronomy Monograph 23. American Society of Agronomy, Crop Science Society of America, and Soil Sci-ence Society of America, Madison, Wisconsin, pp. 155 e17 6.

Shabani, F., Kumar, L., \& Esmaeili, A . (2014). Improvement to the prediction of the USLE K factor. Journal of Geomorphology , 201 (1), $229-234$.

Tribak A., El Garouani A., Abachour M., (2012): Water erosion in tertiary marl series of the Oriental Prerif (Morocco): agents, processes and quantitative evaluation. Rev. Mar. Sci. Agron. Vet. 1, 47-52.

Yjjou M., Bouabid R., El Hmaidi A., Essahlaoui A., El Abassi M., (2014) : Modelisation de l'erosion hydrique via les SIG et l'equation universelle des pertes en sol au niveau du bassin versant de l'Oum Er-Rbia. IJES, Vol 3, Issue 8Pages 83-91.

Wischmeier, W.H., Smith, D.D., (1978). Predicting Rainfall Erosion Losses: a Guide to Conservation Planning. Agriculture Handbook No. 537. USDA, Washington, DC.

Table captions

Table1. Distribution of vegetation cover factor classes in the Ben Ahmed Basin

Table 2. The erosivity index of the rainfall of Ben Ahmed station

Table 3. Spatial distribution of $\mathrm{K}$ factor in the study area

Table 4. Spatial distribution of soil loss

Table 1

\begin{tabular}{llll}
\hline Land use & Class C & Area (ha) & Area (\%) \\
\hline Agriculture land & 0,1 & 406 & 74,5 \\
Bare land & 1 & 122 & 22,4 \\
Built-up & 0 & 17 & 3,1 \\
\hline
\end{tabular}

Table 2

\begin{tabular}{lllllllllllll}
\hline & Sept, & Oct, & Nov, & Dec, & Jan, & Fev, & Mars & Avr, & Mai & Juin & Juil, & Août \\
\hline $\mathrm{P}(\mathrm{mm})$ & 7,11 & 27,62 & 52,87 & 56,9 & 56,12 & 44,67 & 45,64 & 39,89 & 16,64 & 4,55 & 2,31 & 3,38 \\
$\mathrm{R}$ (MJ*mm/ha*heure) & 0,599 & 4,659 & 12,430 & 13,890 & 13,603 & 9,635 & 9,953 & 8,120 & 2,166 & 0,305 & 0,110 & 0,195 \\
\hline
\end{tabular}

Table 3

\begin{tabular}{llll}
\hline Soil type & K Factor & Area (ha) & Area (\%) \\
\hline Vertisols and isohumic soils & $<0,05:$ Very low & 135 & 25,5 \\
Calcareous regosols & $0,1-0,2:$ Moderate & 20 & 3,8 \\
Clayey regosols & $0,2-0,4:$ High & 61 & 11,5
\end{tabular}




\begin{tabular}{llll}
\hline Soil type & K Factor & Area (ha) & Area (\%) \\
\hline Rendzinas & $>0,4:$ Very High & 314 & 59,2 \\
\hline
\end{tabular}

Table 4

\begin{tabular}{lll}
\hline Class of soil losses (t/ha/yr) & Area ( ha) & Area (\%) \\
\hline $0-2,5$ & 482 & 90,1 \\
$2,5-5$ & 22 & 4,1 \\
$5-10$ & 22 & 4,1 \\
$>10$ & 9 & 1,7 \\
\hline
\end{tabular}

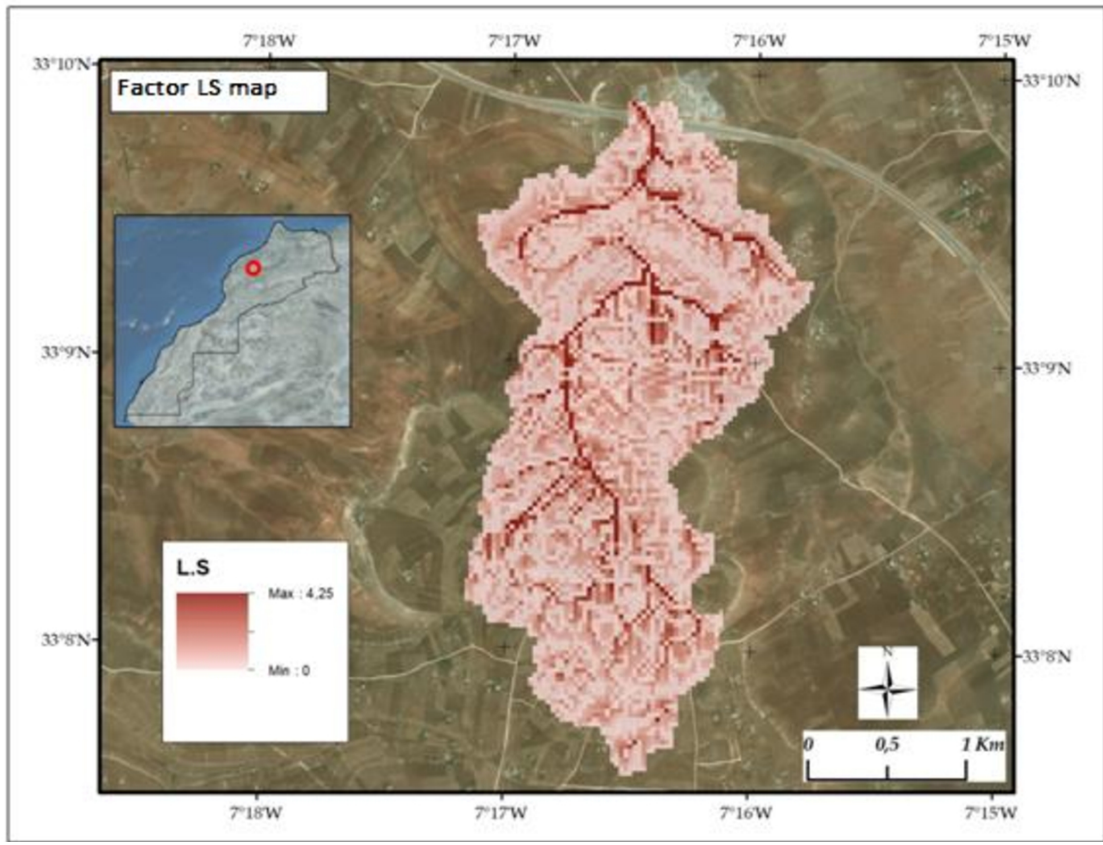



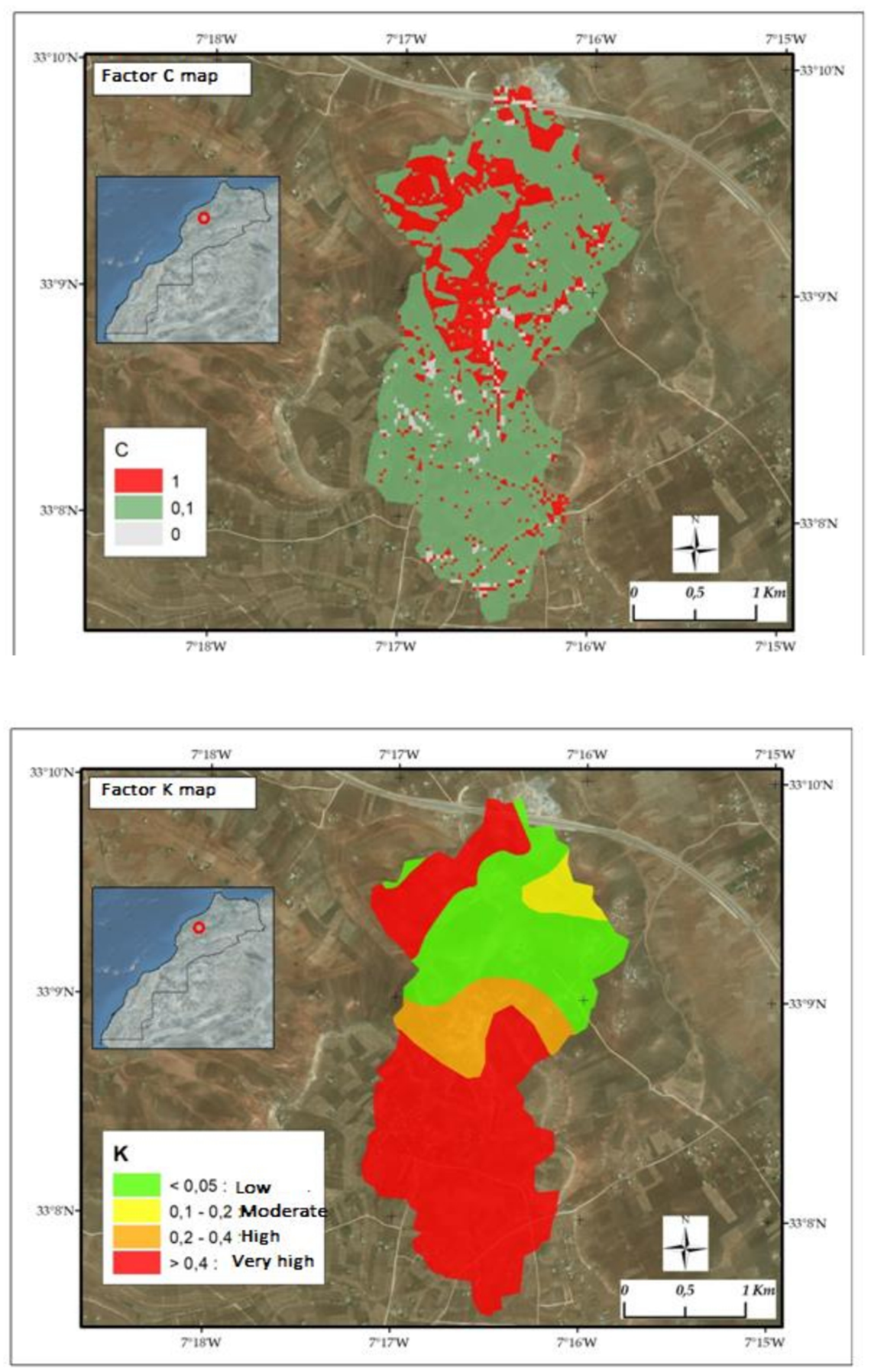


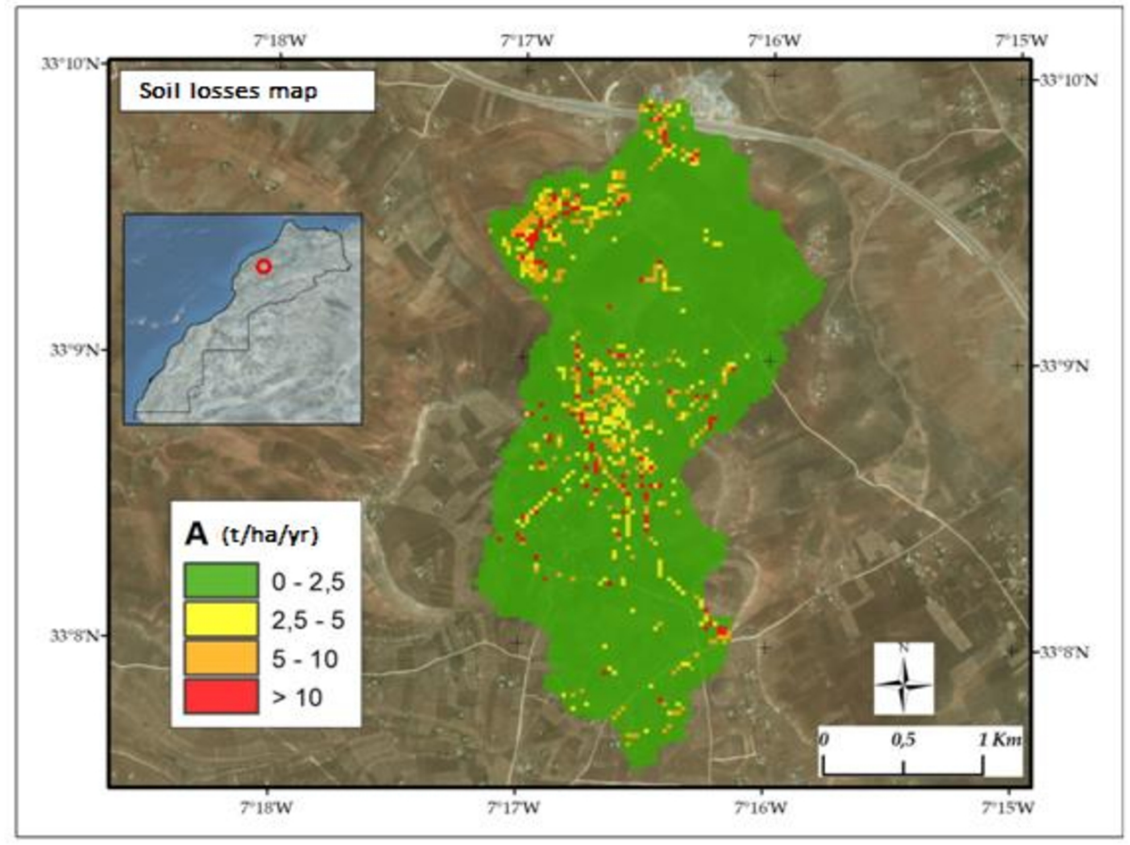

